ISSN: 2162-3104 Print/ ISSN: 2166-3750 Online

Volume 8, Issue 3 (2018), pp. 1363-1385

(C) Journal of International Students

http://jistudents.org/

doi: 10.5281/zenodo.1254596

\title{
Work a Way Out: Breaking Monoethnic Isolation through On-Campus Employment
}

\author{
Mengwei Su \\ Ohio University, USA
}

\begin{abstract}
Since the global economic recession in 2008, Chinese undergraduate students have quickly risen to be the largest international student population in American colleges and universities, forming a monoethnic group that often isolates itself from domestic students on campuses. This study explores how twelve Chinese undergraduate students utilized on-campus employment as a means of engaging host nationals to improve language skills and engage in cross-cultural interactions. Thematic analysis affirms the efficacy of the university workplace as an educational space outside of the classroom. Based on these findings, various policy recommendation are proposed to improve the management of international student employees.
\end{abstract}

Keywords: Chinese international students, cross-cultural interaction, ESL learning, integration, on-campus employment

According to the United States Government Accountability Office (2014), between 2002 and 2012, state funding for all public colleges and universities decreased by $12 \%$ overall while the mean tuition rose by $55 \%$. To secure tuition revenue growth, more and more American colleges and universities began to seek international students from foreign countries. Chinese students soon grew to be the largest group of international students studying in the U.S. (Institute of International Education [IIE], 2017). Among them, the proportion of full-tuition-paying Chinese undergraduate students increased exponentially. Compared with the 2006/07 academic year, a year before the economic recession started, their enrollment skyrocketed by more than twelvefold in the following decade (IIE, 2017). 
International students often suffer from acculturative stress that is normally incurred by language barriers, academic struggles, lack of social support, financial problems, and so on (Melnick, Kaur, \& Yu, 2011; Sherry, Thomas, \& Chui, 2010; Tung, 2011). To make matters worse, they must also cope with the adjustment to American campuses without recoursing to families and friends in their home countries. As a result, it is not an unusual phenomenon that international students become an isolated population within the host country and sometimes even resent the host country's members (Hail, 2015).

Compared with other international students, Asian students are particularly vulnerable. A survey of 141 international students from different American colleges and universities found that Asian students demonstrated higher levels of acculturative stress than do European students (Poyrazli, Kavanaugh, Baker, \& Al-Timimi, 2004). According to the International Student Barometer-a satisfaction survey of 60,000 international students at 48 universities in the United States, the United Kingdom, and Australia, Chinese undergraduate students' overall satisfaction ranked 26th among the thirty largest nationalities (Redden, 2014).

A very promising approach to facilitate Chinese international undergraduate students' integration and development is on-campus employment. Research has shown a positive relationship between oncampus work and American college students' development (Astin, 1993, 1999; Casella \& Brougham, 1995; Cheng \& Alcántara, 2007; Pascarella, Edison, Nora, Hagedorn, \& Terenzini, 1998; Salisbury, Pascarella, Padgett, \& Blaich, 2012). This study posits that on-campus work could also benefit Chinese undergraduate students by providing a constructive environment where international students could engage in language and cultural exchanges.

\section{Definition of the Terms}

The definitions of two critical terms used in this research are provided to ensure readers' understanding.

Chinese International Undergraduate Students are defined as college students from the People's Republic of China who are pursuing a baccalaureate degree at U.S. colleges and universities and hold an F-1 student visa issued by the U.S. embassy. Due to the different political and educational systems, Chinese students from Hong Kong or Taiwan areas are not included in this group.

On-Campus Employment is defined by the Department of Homeland Security as "specific to work that takes place on campus or at an off-campus 
location that is affiliated with the school," and international students "may not work more than 20 hours per week when school is in session" ("Working in the United States," 2016). In this research, on-campus employment refers to the part-time work provided by the university, which pays student workers in the forms of tuition waiver, stipend, or hourly wage. Service learning for course credits, mandatory class projects or internships, volunteer work for student organizations, academic associations, and local communities are not within the scope of this research.

\section{LITERATURE REVIEW}

Studies of the impact of employment on domestic students has generated divergent conclusions depending on the outcome indicators and methodologies adopted in the research. Some scholars raise concerns that work deprives students of study time, which results in poor academic performance and persistence rate (Astin, 1975; Choy, 2002; CuccaroAlamin, 1997; Lammers, Onwuegbuzie, \& Slate, 2001). Other scholars have rebutted such accusations and commended employment for its positive impact on enhancing students' GPA (Horn \& Maw, 1994; Horn, 1998), cognitive development (Pascarella, et al., 1998), leadership ability (Salisbury et al., 2012), involvement in the institution (Astin, 1993, 1999), and employability on graduation (Cheng \& Alcántara, 2007). There is, however, a literature gap in whether student employment could facilitate international students' adjustment and development on campus. This study examines Chinese undergraduate international students' overseas higher education experiences through the lenses of the following three critical areas that are vital to their educational experiences: ESL learning, cross-cultural exploration, and relationship with host nationals.

\section{Learning English in Natural Settings}

Workplaces provide a setting for English as a Second Language (ESL) learning outside of the classroom. In his book, The Study of Second Language Acquisition, Ellis (2008) discusses the main theories of second language acquisition that have emerged since its establishment as a field of study in the 1960s. He lists two situations where the acquisition of a second language normally takes place: educational settings and natural settings. In educational settings, such as classrooms, formal learning occurs, whereas in natural settings (e.g., the workplace), informal learning occurs.

Ellis (2008) suggests that natural settings have two unique advantages over educational settings in facilitating ESL learners' acquisition of a new language: invoking informal learning and producing higher levels of second language proficiency. Scribner and Cole (1973) maintain that 
formal learning tends to acquire knowledge through formulated rules and principles whereas informal learning focuses on providing a demonstration of the knowledge in context. Ellis (2008) further contends that even in natural settings where informal learning is prevalent, ESL learners also intentionally study linguistic rules rather than simply conveying meanings.

\section{Cross-Cultural Exploration}

Besides the lack of ESL preparation, another major source of depressive feelings burdening Chinese international undergraduate students involves acculturation barriers. Berry (2005) defines acculturation as "the dual process of cultural and psychological change that takes place as a result of contact between two or more cultural groups and their individual members" (p. 698). During cross-cultural exploration, according to Berry, individuals will inevitably face conflicts and look for negotiation between the two cultural groups. Before the term of acculturation was coined, Oberg (1960) found a similar transition of how individuals adjust to a foreign culture. The essence of his four-stage model of the culture shocks theory is overcoming the rejection to an unfamiliar environment and producing adaptation accordingly by improving language ability and expanding social interaction. In sum, both Berry and Oberg suggested that conflicts are inevitable during the process of acculturation and overcoming conflicts helps individuals develop multicultural competency. International students who immerse themselves in a new, foreign American college setting are not exceptional to these kind of conflicts; in fact, they expect to experience such struggle and learn from it, because it is an indispensable part of their educational goals of studying abroad.

\section{Bonding Host Nationals}

It is difficult for international students to make substantial progress in ESL learning or culture transmission without interacting with host nationals. Despite the fact that monocultural friendships can be vital in reducing international students' distress in transition (Bochner et al., 1977, Rose-Redwood \& Rose-Redwood, 2013; Ye, 2006), some scholars claim that contact with host nationals is one of the most important friendship bonds to facilitate international student success in a new cultural context (Y.Y. Kim, 2000; Ward, Bochner, \& Furnham, 2001). For instance, a survey of 497 international graduate students at an American research university indicated that students who socialized with Americans the most not only adapted to American culture more comfortably but also actively socialized with other international students and participated in campus cultural events (Trice, 2004). Another mail survey of 170 international undergraduate 
students who attended U.S. colleges and universities showed that building interpersonal relationships with Americans not only improved their written and oral English language skills but also enhanced their perceived selfesteem (Barratt \& Huba, 1994).

Both Bochner, McLeod, and Lin (1977) and Rose-Redwood and Rose-Redwood (2013) observe that the primary relationship international students have with American host nationals is academic-related. A problem with the current cross-cultural interaction between international and domestic students is that even when they manage to establish some forms of contact, the depth of the relationship remains shallow. Gresham and Clayton (2011) conclude from their extensive review of the literature that it is a daunting task for international students to transform their relationships with host nationals from having small talk to meaningful connections that could contribute to their success on foreign campuses. The focus of the present study is to probe whether on-campus employment can enhance the depth of the interaction between Chinese international students and host nationals.

\section{RESEARCH METHOD}

This study adopted a qualitative methodology and chose phenomenological inquiry as an approach to conducting data collection and analysis. Lichtman (2013) defines this method by noting that "[p]henomenology, as an approach, looks at the lived experiences of those who have lived with or experienced a particular phenomenon" (p. 85). This approach "interrogates phenomena which are not reducible to facts" (Giorgi, 2008, p. 2). In this study, I did not try to measure Chinese undergraduate students' improvement in ESL acquisition and cultural transmission, nor did I seek to assess the satisfaction in networking with host nationals as an objective or existential fact. Rather, I saw these dependent variables as a perception of the experience the participants had. Therefore, I attempted to seek a deep understanding of how the participants navigated in the workplace on campus and how they interpreted its educational outcome.

Three research questions guided this study:

1. How do Chinese international undergraduate students learn English in the workplace on campus?

2. What new cultural practices do Chinese international undergraduate students learn about in the workplace on campus?

3. What kind of social relationships do Chinese international undergraduate students make in the workplace on campus? 
Table 1. Participants' demographics.

\begin{tabular}{|c|c|c|c|c|}
\hline Pseudonym & Gender & State & Institution type & Major \\
\hline \multirow[t]{3}{*}{ Hui } & M & Illinois & $\begin{array}{l}\text { Public community } \\
\text { college }\end{array}$ & Pre-Academic \\
\hline & & Illinois & $\begin{array}{l}\text { Private comprehensive } \\
\text { university }\end{array}$ & Pre-Engineering \\
\hline & & Ohio & $\begin{array}{l}\text { Public research } \\
\text { university }\end{array}$ & $\begin{array}{l}\text { Electrical } \\
\text { Engineering }\end{array}$ \\
\hline Han & M & Wisconsin & $\begin{array}{l}\text { Public research } \\
\text { university }\end{array}$ & Business \\
\hline Jie & $\mathrm{F}$ & $\begin{array}{l}\text { South } \\
\text { Carolina }\end{array}$ & $\begin{array}{l}\text { Public liberal arts } \\
\text { college }\end{array}$ & Public Health \\
\hline Fei & $\mathrm{F}$ & Ohio & $\begin{array}{l}\text { Public research } \\
\text { University }\end{array}$ & $\begin{array}{l}\text { Political Science; } \\
\text { Economics }\end{array}$ \\
\hline Sheng & M & Oregon & $\begin{array}{l}\text { Public flagship research } \\
\text { university }\end{array}$ & Economics \\
\hline Jing & $\mathrm{F}$ & Ohio & $\begin{array}{l}\text { Public research } \\
\text { university }\end{array}$ & Biology \\
\hline Feng & $\mathrm{F}$ & New York & $\begin{array}{l}\text { Public liberal arts } \\
\text { college }\end{array}$ & English Literature \\
\hline Yue & M & Ohio & $\begin{array}{l}\text { Public research } \\
\text { university }\end{array}$ & Pre-Academic \\
\hline Zhou & $\mathrm{F}$ & Ohio & $\begin{array}{l}\text { Public research } \\
\text { university }\end{array}$ & Education \\
\hline Ming & M & Indiana & $\begin{array}{l}\text { Public flagship } \\
\text { university }\end{array}$ & $\begin{array}{l}\text { Economics; } \\
\text { Mathematics }\end{array}$ \\
\hline Sun & M & Ohio & $\begin{array}{l}\text { Public research } \\
\text { university }\end{array}$ & $\begin{array}{l}\text { Management } \\
\text { Information } \\
\text { System }\end{array}$ \\
\hline Xiong & $\mathrm{F}$ & $\begin{array}{l}\text { South } \\
\text { Carolina }\end{array}$ & $\begin{array}{l}\text { Public liberal arts } \\
\text { college }\end{array}$ & $\begin{array}{l}\text { Tourism and Hotel } \\
\text { Mgt. }\end{array}$ \\
\hline
\end{tabular}




\section{Participants}

Three sampling techniques were utilized in recruiting participants. Using snowball sampling, I first identified a few participants from my former ESL students and then asked them to invite their friends to join the study. As the key to a successful phenomenology inquiry is the depth of the data, I also adopted maximum variation sampling and selected participants who had as much variation in demographic factors and work experiences as possible. Lastly, when deciding the sample size, I utilized saturation sampling, which continues to add participants as fieldwork proceeds until new patterns cease to emerge (Patton, 2014).

For phenomenological inquiries, Morse (1994) suggests that six interviews should be the smallest acceptable sample size. Creswell (2007), on the other hand, recommends the sample size ranging between five and twenty-five interviews. In this study, of the total of 14 interviews I conducted, I used 12 of them for data analysis and discarded two that contained recurring information. Table 1 and Table 2 below depict an overview of the demographics and work experiences of the participants.

Table 2. Participants' work experiences.

\begin{tabular}{|c|c|c|c|c|}
\hline Pseudonym & Employment & $\begin{array}{l}\text { Starting } \\
\text { year }\end{array}$ & Starting status & $\begin{array}{l}\text { Length of } \\
\text { work }\end{array}$ \\
\hline \multirow[t]{5}{*}{ Hui } & $\begin{array}{l}\text { Restaurant } \\
\text { Delivery (off- } \\
\text { campus) }\end{array}$ & Fall, 1995 & Pre-Academic & 1.5 year \\
\hline & $\begin{array}{l}\text { Merchandise } \\
\text { Delivery (off- } \\
\text { campus) }\end{array}$ & $\begin{array}{l}\text { Spring, } \\
1997\end{array}$ & First-year & 3 times \\
\hline & $\begin{array}{l}\text { Bell Ringer (off- } \\
\text { campus) }\end{array}$ & $\begin{array}{l}\text { Winter, } \\
1998\end{array}$ & Second-year & 1 month \\
\hline & Culinary Services & Fall, 1998 & Second-year & 1 years \\
\hline & Escort Service & Fall, 1999 & Third-year & 2 years \\
\hline \multirow[t]{2}{*}{ Han } & Culinary Services & Fall, 2012 & First-year & 3.5 years \\
\hline & IT Services & Fall, 2014 & Third-year & 2 years \\
\hline Jie & $\begin{array}{l}\text { Orientation } \\
\text { Leader }\end{array}$ & $\begin{array}{l}\text { Summer, } \\
2015\end{array}$ & Second-year & 1 summer \\
\hline
\end{tabular}




\begin{tabular}{|c|c|c|c|c|}
\hline Pseudonym & Employment & $\begin{array}{c}\text { Starting } \\
\text { year }\end{array}$ & Starting status & $\begin{array}{l}\text { Length of } \\
\text { work }\end{array}$ \\
\hline Fei & Resident Assistant & Fall, 2011 & Second-year & 2.5 years \\
\hline Sheng & Culinary Services & $\begin{array}{l}\text { Spring, } \\
2013\end{array}$ & Third-year & 1 semester \\
\hline \multirow[t]{2}{*}{ Jing } & Culinary Services & $\begin{array}{l}\text { Summer, } \\
2009\end{array}$ & Pre-Academic & 1 summer \\
\hline & Lab Assistant & Fall, 2012 & Second-year & 4 years \\
\hline Feng & $\begin{array}{l}\text { Cultural } \\
\text { Ambassador }\end{array}$ & $\begin{array}{l}\text { Spring, } \\
2016\end{array}$ & Second-year & 1 semester \\
\hline Yue & Culinary Services & $\begin{array}{l}\text { Summer, } \\
2015\end{array}$ & Pre-Academic & $\begin{array}{l}1 \text { year, and } \\
\text { counting }\end{array}$ \\
\hline \multirow[t]{5}{*}{ Zhou } & $\begin{array}{l}\text { Supplementary } \\
\text { Instructor }\end{array}$ & Fall, 2012 & Second-year & 4 years \\
\hline & Tutor & Fall, 2012 & Second-year & 4 years \\
\hline & $\begin{array}{l}\text { Global } \\
\text { Ambassador }\end{array}$ & Fall, 2012 & Second-year & 1 year \\
\hline & $\begin{array}{l}\text { ESL Instructor } \\
\text { (off-campus) }\end{array}$ & $\begin{array}{l}\text { Summer, } \\
2012\end{array}$ & Second-year & 3 summers \\
\hline & $\begin{array}{l}\text { Administration } \\
\text { Assistant (off- } \\
\text { campus) }\end{array}$ & $\begin{array}{l}\text { Summer, } \\
2012\end{array}$ & Second-year & 3 summers \\
\hline Ming & Culinary Services & $\begin{array}{l}\text { Spring, } \\
2014\end{array}$ & Second-year & 1 semester \\
\hline \multirow[t]{3}{*}{ Sun } & Culinary Services & $\begin{array}{l}\text { Spring, } \\
2015\end{array}$ & Second-year & 1 semester \\
\hline & $\begin{array}{l}\text { Waiter (off- } \\
\text { campus) }\end{array}$ & Fall, 2015 & Third-year & 2 semesters \\
\hline & $\begin{array}{l}\text { Chinese Instructor } \\
\text { (off-campus) }\end{array}$ & Fall, 2015 & Third-year & 2 semesters \\
\hline Xiong & $\begin{array}{l}\text { Global } \\
\text { Ambassador }\end{array}$ & $\begin{array}{l}\text { Spring, } \\
2016\end{array}$ & First-year & 1 semester \\
\hline
\end{tabular}




\section{Interviewing}

To address the research questions, I used one-on-one, semistructured interviews to collect data. At the beginning of each interview, I reminded the participants of the confidential nature of the study. The language used for this study's interviews was Chinese, because communicating in participants' mother tongue allowed them to express complicated feelings and thoughts and at the same time enhanced the rapport between the researcher and the participants.

\section{Coding and Thematic Categorizing}

Phenomenological inquiry not only procures abundant descriptive data of the participants' lived experiences but also captures the themes emerging from the rich narratives. After transcribing and translating the data, I coded the text that had interpreted meanings. Then, based on "recurring regularities or patterns" among the codes (Merriam, 2009, p. $180)$, I consolidated the codes into a small number of meaningful concepts, or themes, that were pertinent to the research questions.

\section{RESULTS}

Four distinctive themes were produced through data analysis: motivation for work, ESL acquisition, new culture encountered, and contact with host nationals.

\section{Taking Part-Time Work for Non-Financial Reasons}

In this research, I found that financial reward was not the main motivation for the new generation of Chinese undergraduate students to engage in on-campus employment. With the exception of one participant, Hui, all the participants came to the U.S. for higher education after 2010. Although the financial abilities of these participants' families differed from each other, the participants were all from comparatively affluent families in China. Their parents prepared sufficient funds for not only their tuition but also the living costs. The financial status of the new generation of Chinese undergraduate students contrasts with Hui, who came to the U.S. for higher education in 1995. His family had a good income back then, but it was no match for the new middle-class families after more than a decade of fast economic growth in China. Table 3 illustrates what the participants' initial motives were to start their first job on campus. 
Table 3. Participants' initial motives to work.

\begin{tabular}{ll}
\hline Pseudonym & \multicolumn{1}{c}{ Initial motive } \\
\hline Hui & "If I did not work, I could survive, but not for long." \\
Han & "I wanted to get my SSN through on-campus employment." \\
Jie & "The administrator at the International Student Office recommended me \\
this job, telling me it would build up my resume." & "I noticed the two RAs in my residence hall were from China...If those \\
Fei & $\begin{array}{l}\text { two Chinese girls can do this job, so can I." } \\
\text { "My main motivation was to improve myself, particularly my ESL } \\
\text { proficiency." }\end{array}$ \\
Jing & $\begin{array}{l}\text { "I was studying ESL, and I had a lot of free time. I wanted to make } \\
\text { Feng }\end{array}$ \\
"Makican friends and know more about the American society." \\
"Mecause I plan to apply for graduate schools in the future."
\end{tabular}

\section{Improving ESL Learning in Natural Settings}

In this research, I found that most of the participants reported having achieved a certain level of improvement in ESL proficiency through their on-campus employment. Table 4 lists the participants' indications of their ESL levels before and after they took on-campus jobs. The only two participants who did not consider on-campus employment to have any significant impact on their ESL acquisition were Hui and Zhou. Both had participated in English immersion before they started working on campus, 
which they considered more pivotal in helping them improve ESL compared to their campus employment experiences.

Table 4. Participants' ESL improvement.

\begin{tabular}{|c|c|c|c|}
\hline Pseudonym & Jobs & ESL level before work & ESL level after work \\
\hline Hui & $\begin{array}{l}\text { Restaurant and } \\
\text { Merchandise } \\
\text { Delivery; } \\
\text { Bellringer; } \\
\text { Culinary } \\
\text { Services; Safe } \\
\text { Transportation } \\
\text { Service }\end{array}$ & $\begin{array}{l}\text { "My English was not bad } \\
\text { when I started to work." }\end{array}$ & $\begin{array}{l}\text { "My jobs did not have a } \\
\text { high requirement for ESL } \\
\text { proficiency." }\end{array}$ \\
\hline Han & $\begin{array}{l}\text { Culinary } \\
\text { Services; } \\
\text { IT Services }\end{array}$ & $\begin{array}{l}\text { "When I first arrived on } \\
\text { campus, my English was } \\
\text { poor." }\end{array}$ & $\begin{array}{l}\text { "I began to chit-chat with } \\
\text { the domestic coworkers } \\
\text { in the second semester." }\end{array}$ \\
\hline Jie & $\begin{array}{l}\text { Orientation } \\
\text { Leader }\end{array}$ & $\begin{array}{l}\text { "The administrator knew } \\
\text { I had my high school in } \\
\text { the States and my English } \\
\text { is qualified for this job." }\end{array}$ & $\begin{array}{l}\text { "I improved my } \\
\text { English... I did not say a } \\
\text { Chinese word for the } \\
\text { entire summer...My } \\
\text { colleagues praised my } \\
\text { progress." } \\
\text { "I improved my ability in } \\
\text { public speaking." }\end{array}$ \\
\hline Fei & $\begin{array}{l}\text { Resident } \\
\text { Assistant }\end{array}$ & $\begin{array}{l}\text { "I had no problems in } \\
\text { basic communication in } \\
\text { the second year." }\end{array}$ & $\begin{array}{l}\text { "My job responsibility as } \\
\text { an RA required me to } \\
\text { communicate with the } \\
\text { domestic students... This } \\
\text { job helped me understand } \\
\text { the American cultures." }\end{array}$ \\
\hline Sheng & $\begin{array}{l}\text { Culinary } \\
\text { Services }\end{array}$ & $\begin{array}{l}\text { "I had no problems in } \\
\text { basic communication } \\
\text { when I arrived on } \\
\text { campus." }\end{array}$ & $\begin{array}{l}\text { "I improved a lot... To be } \\
\text { able to join their } \\
\text { conversations, I paid } \\
\text { attention to the hot topics } \\
\text { among the domestic } \\
\text { students." }\end{array}$ \\
\hline
\end{tabular}




\begin{tabular}{|c|c|c|c|}
\hline Jing & $\begin{array}{l}\text { Culinary } \\
\text { Services; } \\
\text { Lab Assistant }\end{array}$ & $\begin{array}{l}\text { "I started working in the } \\
\text { dining hall while I was } \\
\text { still in the ESL remedial } \\
\text { program." }\end{array}$ & $\begin{array}{l}\text { "I improved my academic } \\
\text { English greatly by } \\
\text { working in the lab." }\end{array}$ \\
\hline Feng & $\begin{array}{l}\text { Cultural } \\
\text { ambassador }\end{array}$ & $\begin{array}{l}\text { "I passed TOEFL...I } \\
\text { majored in English } \\
\text { literature." }\end{array}$ & $\begin{array}{l}\text { "My job does not require } \\
\text { me to speak English a } \\
\text { lot...I learned news } \\
\text { words unrelated to my } \\
\text { major through text } \\
\text { translating." }\end{array}$ \\
\hline Yue & $\begin{array}{l}\text { Culinary } \\
\text { Services }\end{array}$ & $\begin{array}{l}\text { "I am studying ESL and } \\
\text { enrolled in Pre- } \\
\text { Academic." }\end{array}$ & $\begin{array}{l}\text { "I improved my verbal } \\
\text { English." }\end{array}$ \\
\hline Zhou & $\begin{array}{l}\text { Supplementary } \\
\text { Instructor; Tutor; } \\
\text { Global } \\
\text { Ambassador; } \\
\text { ESL Instructor; } \\
\text { Administration } \\
\text { Assistant }\end{array}$ & $\begin{array}{l}\text { "I spent three years } \\
\text { studying high school } \\
\text { curriculum in Australia." }\end{array}$ & $\begin{array}{l}\text { "I have had no language } \\
\text { barrier at work." }\end{array}$ \\
\hline Ming & $\begin{array}{l}\text { Culinary } \\
\text { services }\end{array}$ & $\begin{array}{l}\text { "I usually just listened to } \\
\text { what other people talk in } \\
\text { class. }\end{array}$ & $\begin{array}{l}\text { "I learned a lot... I had to } \\
\text { keep talking with my } \\
\text { coworkers in the dining } \\
\text { hall." }\end{array}$ \\
\hline Sun & $\begin{array}{l}\text { Culinary } \\
\text { Services; Waiter; } \\
\text { Chinese } \\
\text { Instructor }\end{array}$ & $\begin{array}{l}\text { "I was studying ESL at } \\
\text { that time." }\end{array}$ & $\begin{array}{l}\text { "Working (in the dining } \\
\text { hall) transferred me to } \\
\text { speak English willingly." }\end{array}$ \\
\hline Xiong & $\begin{array}{l}\text { Global } \\
\text { Ambassador }\end{array}$ & $\begin{array}{l}\text { "When I joined the } \\
\text { office, I could barely } \\
\text { speak English, and I did } \\
\text { not dare to speak, either." }\end{array}$ & $\begin{array}{l}\text { "The English I learned in } \\
\text { the workplace was more } \\
\text { colloquial...I did a lot of } \\
\text { text translation work." }\end{array}$ \\
\hline
\end{tabular}

\section{Encountering Cultural Differences}

The twelve participants all depicted their emotional and intellectual reactions toward the American cultural practices they had experienced in the workplace. Many of these new values and beliefs contradicted the old ones they held in their home country. In general, all the participants, who grew up in upper-class Chinese families, reported that they were impressed by their 
American peers' financial independence, and they learned the value of a buck through earning minimum wages. Seven participants who worked in the university culinary services reported that the respect they had at work made them admire America's egalitarian ethos and feel sorry for how working-class laborers in China were commonly treated.

Participants' work stories revealed that their employment exposed them to various diversity issues that they had never encountered before. For instance, after getting acquainted, Ming's coworker started talking about his partner. When Ming asked him, "How old is she?," his coworker corrected him, "It's he." Ming apologized immediately for his assumption although he was quite surprised inside at the time. The LGBT issue is still a taboo in China and is not openly addressed by either the government or the educational institutions. By routinely working and interacting with their gay coworkers, Ming concluded that "gay people are just like normal people," and "they are equal human beings." Another participant Fei, who worked as a Resident Assistant, even had the opportunity to take a class and training in diversity before she started to work, and she became a staunch supporter of gay rights.

In some cases, the clashes between two cultures were harder for the participants to resolve. For example, a student diner came to Sheng's window shortly before closing and asked for gravy. When Sheng told the student that he had run out of it, his supervisor corrected him on site and told him to make a whole new bowl of gravy just to serve that one student's request. In reflection, Sheng re-examined the different practices between the American and Chinese college dining halls, and he expressed his admiration of the American culture of always putting customers in the first place, even though he still did not agree with the food waste.

\section{Building Relationships with the Host Nationals}

In this research, I investigated the depth of the relationships that participants had with their American colleagues. The criterion used for measurement was whether the participants feel the friendship provides any emotional or professional support to them. If a participants' descriptions of the relationship met the criterion, then that relationship was categorized as "satisfactory"; if not, it was categorized as "unsatisfactory." Table 5 illustrates the result of such categorization: five out of the twelve participants built satisfactory relationships with host nationals. 
Table 5. Participants' relationships with host nationals.

\begin{tabular}{|c|c|c|}
\hline Pseudonym & Relationship & Type \\
\hline Hui & $\begin{array}{l}\text { "I had had a circle of Asian friends already." } \\
\text { "Domestic students from big cities were more } \\
\text { embracing international students than those from } \\
\text { small towns." } \\
\text { "Domestic students had their ways of socialization, } \\
\text { e.g., hanging out in bars on weekends." }\end{array}$ & Unsatisfactory \\
\hline Han & $\begin{array}{l}\text { "My boss appreciated my work because I was there } \\
\text { for a long time." } \\
\text { "My domestic coworkers would invite me to their } \\
\text { house parties on weekends." }\end{array}$ & Unsatisfactory \\
\hline Jie & $\begin{array}{l}\text { "At first, I was very upset that I could not make } \\
\text { friends with my coworkers." } \\
\text { "The administrators of the office volunteered to } \\
\text { teach me how to drive on weekends...They let me } \\
\text { practice with their cars." } \\
\text { "I still go to them for advice after the summer job } \\
\text { was over." }\end{array}$ & Satisfactory \\
\hline Fei & $\begin{array}{l}\text { "My coworker and I did floor check together every } \\
\text { night... We became friends naturally." }\end{array}$ & Satisfactory \\
\hline Sheng & $\begin{array}{l}\text { "To be frank, there was not enough time for me to } \\
\text { make any friends (in the dining hall)... My } \\
\text { coworkers were friendly to me, but we did not have } \\
\text { communications after work." }\end{array}$ & Unsatisfactory \\
\hline Jing & $\begin{array}{l}\text { "I had good relationships with both of my } \\
\text { professors... My boss encouraged me to apply for a } \\
\text { research fund from the University... Under his } \\
\text { guidance, I wrote a research proposal." }\end{array}$ & Satisfactory \\
\hline Feng & $\begin{array}{l}\text { "I did not have American coworkers." } \\
\text { "My supervisor gave us flexible work hours... I just } \\
\text { need to say hello when I saw her in office." }\end{array}$ & Unsatisfactory \\
\hline Yue & $\begin{array}{l}\text { "Once there was a girl coworker who invited me to } \\
\text { her party in a bar." }\end{array}$ & Unsatisfactory \\
\hline
\end{tabular}


Zhou

"My professor promoted me to be the team leader."

Satisfactory

"I could talk about any work-related problems with him."

"After I became the team leader, few coworkers talked to me anymore."

"You know there is always a 'wall' between the American people and us. We could hug each other, but it still does not feel the same as being with your compatriots."

Ming "They invited me to drink...I went for a couple of times...We stopped contacting after I left the job...We were not good friends."

Sun

"I did not make any friends from work."

"The restaurant owner treated me like his child."

"The owner of the Chinese language school invited

Unsatisfactory me to live in his house free of charge."

Xiong

"The director of the project treated our Chinese

Satisfactory students with special care... She was like a mom to Unsatisfactory; satisfactory ${ }^{\mathrm{a}}$ us...During the holidays, she would drive us to the Asian supermarket for grocery shopping and eat hotpot with us."

\footnotetext{
${ }^{\text {a }}$ Sun built satisfactory relationship with the host nationals at off-campus workplace.
}

\section{DISCUSSION}

Previous studies of on-campus employment have only focused on its impact on domestic students. In this study, I explored how the setting of the workplace on campus benefited the development of Chinese international undergraduate students.

\section{New Setting for ESL Acquisition}

The most prominent advantage of learning English in the workplace on campus is that this natural setting creates various contexts where ESL learners find different knowledge and usage of the English language. The participants of the study repeatedly noted that the English they learned in the classrooms was "formal," "academic," or "major-related." In contrast, they appreciate how their on-campus jobs allow them to gain more contacts with the native speakers, had more opportunities to practice the target language, and focus on communicative messages rather than grammatical rules. 
Participants were compelled to write work reports, communicate with supervisors, and cope with work issues. If they had not taken the part-time job, they would not have learned and practiced English in those language contexts.

On the other hand, the new language contexts could also be nonwork related. The topics that the participants talked with their American colleagues about were quite broad: academics, entertainment, sports, politics, etc. These ESL contexts tested participants' familiarity with American culture. For instance, a job that few would expect to be languagechallenging is the culinary services. Although it is labor-intensive, participants who worked at the university dining halls were not laden with labor duties all the time; after the rush hours, they all reported having the necessity of striking small talk conversations with their American coworkers as well as the student diners. To be able to engage in conversations with domestic students, some participants endeavored to learn about culturerelated topics, which constitute a wide range of language contexts. The following quote from one participant, Sheng, epitomizes such aspiration:

When I served meals, I did not just want to go through the motions quietly; I wanted to talk with the student diners like my American coworkers did. They chitchatted about fun stuff and made jokes. To reach that goal, I made extra efforts in learning.

\section{New Setting for Cross-Cultural Exploration}

In this research, fewer than half of the participants had built satisfactory relationships with their American colleagues, which corroborated Yang, Teraoka, Eichenfield, and Audas's (1994) study. However, we must not conclude hastily that on-campus employment is an ineffective means for cross-cultural exploration on campus. On the contrary, the efficacy of on-campus employment is best reflected in how it propels international students and host nationals to interact with each other.

\section{At International Students' End}

Bochner, McLeod, and Lin (1977) found that Asian international students rely on the conational network for cultural affirmation and expression as their fundamental relationship. Al-Sharideh and Goe's (1998) study aligns with Bochner et al. as it found ethnic community helps boost international students' self-esteem. However, they also indicated that involvement exclusively in the ethnic community has a counterproductive effect. In many American colleges and universities, Chinese students have grown to be the largest segment of the international student population, which leaves them prone to becoming "self-segregators"-international 
students who "socially interact only with conationals, excluding other nationals and host nationals" (Rose-Redwood \& Rose-Redwood, 2013, p. 419). Findings of this study affirm on-campus employment is without a doubt a good pathway to lead Chinese undergraduate students to break through their language and cultural barricades.

Notably, cross-cultural exploration is not always pleasant. Both Berry (2005) and Oberg (1960) suggest that conflicts are inevitable during the process of acculturation and overcoming conflicts helps individuals develop multi-cultural competency. Findings of this study show working on campus makes it more possible for Chinese undergraduate students to experience the clashes of different cultures than studying in the classroom. Participants readily bonded with host nationals who provided them with the emotional or professional support they needed during cross-cultural exploration, and they found this type of intercultural relationships more satisfying than the purely recreational ones.

\section{At Domestic Students' End}

Meanwhile, on-campus employment also instigates domestic students to engage in cross-cultural interactions. Previous studies indicate that most domestic students perceive international students favorably, yet few of them would make extra efforts to contact their international peers (Ward, 2001). Barriers such as language, indifference, ethnocentrism, etc., hinder host nationals from responding to international students' need for close contacts and interaction (Brown, 2009; Hail, 2015; Volet \& Ang, 1998). This research not only verified that the participants had been treated nicely in the workplace but also revealed evidence of the initiatives shown by their American colleagues to bond with the participants.

Compared with other efforts to foster cross-cultural interactions on campus, bonding with international students in the workplace is less burdening to domestic students. In 2009, the University of Newcastle launched a pilot project which recruited and trained domestic students to befriend international students (Gresham \& Clayton, 2011). International students who applied for this project had the opportunity to meet domestic student volunteers and do activities together, such as studying, sharing food, watching movies, shopping, playing sports, and so on. Although it was a successful experiment, the domestic participants reported having difficulty in finding the time and common interests with the international participants; furthermore, over time a certain pressure of taking care of international student friends accrued on their shoulders. In this study, the bond between the participants and their domestic coworkers stemmed naturally from a 
professional relationship. No host nationals felt obliged to take part in crosscultural interactions during work.

\section{IMPLICATIONS}

Schlossberg (2011) indicates the importance of organizational assistance to the wellbeing of the people who are coping with work transitions. Hence, this study suggests that the following three recommendations to university administrators and personnel can provide strategies for managing Chinese student employees more effectively.

\section{Increase Cross-Cultural Interactions}

The findings of this research indicate that few Chinese undergraduate students are motivated by financial reasons to take up oncampus jobs. Most of them aim to improve ESL, make new friends, learn about American culture, or build a resume. Interactions with host nationals are an indispensable part of the work experience for them to realize their goals. Moreover, most participants in the study who worked in the dining halls joined the on-campus workforce mainly as a quick way to procure social security number. Nonetheless, in reflection, they spoke highly about the contact they had with their American coworkers as well as the student diners because they had improved ESL and cultural competence through the interactions they had with them. A notable good practice of a few college culinary services in this study is that they do not assign the Chinese undergraduate students to work together; instead, they paired them with domestic students on the same shift. The participants appreciated this kind of opportunity for cross-cultural interactions, and they considered it as a good learning experience at work.

Besides coworkers, supervisors are also the key host nationals that Chinese student workers have cross-cultural interactions with in the workplace. Compared with the students, supervisors are more competent to act as the mediating person who bridges between cultures (Bochner, 1981). They are capable of creating the cross-cultural connections partnership (Robinson, Wolffe, Hunt, \& Hoerr, 2002) with international student employees, providing "real-world, multicultural experiences that would help the students involved strengthen their individual self-identities while heightening their appreciation of diversity" (p. 537). In this research, participants spoke highly of the relationships they had with their supervisors who helped them navigate through the new cultural environment. These supervisors not only supported the participants in the workplace but also spent their private time connecting with the participants. For instance, they 
went to Chinese restaurants with the students, gave the students rides to buy groceries at Asian supermarkets, or they taught the students how to drive in the U.S. Such activities have brought the participants the most joyful memories of their work experiences.

\section{Allow Room for Mistakes}

Coming from an educational culture that is known for rigorousness and sometimes even fastidiousness, many Chinese international students hold high standards and high expectations for themselves. A study of the causes of college students' social anxiety found that, compared with Caucasian students, mainland Chinese students are more susceptible to socially prescribed perfectionism (Xie, Leong, \& Feng, 2008). Every participant in this research indicated that their on-campus job in the U.S. was the first formal paid work they had ever had in life, let alone in a foreign country. Despite receiving training before going on duty, they were anxious about not being able to perform their work duties well.

Therefore, many of the participants expressed thankfulness to their supervisors for showing the forbearance at the times when they made mistakes on the job. One participant, Sun, had work experiences both on and off campus, and he indicated that the former setting was more tolerant of mistakes. Indeed, another participant, Zhou, even considered it as advantageous to make mistakes early in college and learn lessons before entering the full-time workforce. By providing an uninhibited work environment, university student employment supervisors could mitigate Chinese undergraduate student employees' work stress when they are climbing the learning curve.

\section{Be Racially and Culturally Sensitive}

Most Chinese international undergraduate students are undergoing a unique racial identity transition from being a majority group to a minority group after arriving in the States. Racial identity theorists have indicated that ethnic adolescents will go through a multi-phased racial identity transition before they eventually reach multiculturalism (Cross et al., 1991; E. Kim, 2012; Phinney, 1993). When initially exposed in a majority group, they will have a heightened racial consciousness and often reject the main culture.

Having understood the ethnic adolescents' racial identity development, college student supervisors should develop racial and cultural sensitivity when managing international student employees. Especially when making a criticism, host-national supervisors should realize that the same disapproval they give to the domestic students and international 
students might result in different reactions. In this study, participants reported a few unhappy interactions with American student managers and supervisors, who, for example, made sarcastic comments when finding their directives not understood by the participants, or referred the participants collectively as "you Chinese students," etc. Being racially and culturally sensitive could mean that college student supervisors may need to be more patient and explanatory with international student employees to avoid inadvertent misunderstandings.

\section{CONCLUSION}

While international students are catalysts to campus diversity, the transformation of a university into a global community for knowledge and cultural exchange is a slow process. Over the past decade, the number of international students has quickly topped the one-million benchmark in the U.S., and nearly a third of them come from China (IIE, 2017). Although the surge of international student enrollment generated anticipated economic value, it also exacerbated the isolation problem between international students and their domestic peers (Su \& Harrison, 2016).

To address this problem, I investigated whether on-campus employment could be used as a remedy. The research findings from this study suggest that Chinese undergraduate students who have taken part-time jobs in American colleges and universities generally showed positive results. Working on campus helped the participants to break through their monoethnic isolation and provided them access to engaging host nationals. Therefore, on-campus workplace constitutes as a supplementary educational space for cross-cultural academic and social learning in the university.

\section{REFERENCES}

Al-Sharideh, K.A., \& Goe, W.R. (1998). Ethnic communities within the university: An examination of factors influencing the personal adjustment of international students. Research in Higher Education, 39(6), 699-725.

Astin, A.W. (1975). Preventing students from dropping out (1st ed.). San Francisco, CA: Jossey-Bass.

Astin, A.W. (1993). What matters in college? Four critical years revisited. San Francisco, CA: Jossey-Bass.

Astin, A.W. (1999). Student involvement: A developmental theory for higher education. Journal of College Student Development, 40(5), 518-529.

Barratt, M.F., \& Huba, M.E. (1994). Factors related to international undergraduate student adjustment in an American community. College Student Journal, $28(4), 422-436$. 
Berry, J.W. (2005). Acculturation: Living successfully in two cultures. International Journal of Intercultural Relations, 29(6), 697-712.

Bochner, S. (1981). The mediating person: Bridges between cultures. Cambridge, MA: G.K. Hall.

Bochner, S., McLeod, B.M., \& Lin, A. (1977). Friendship patterns of overseas students: A functional model. International Journal of Psychology, 12(4), 277-294.

Brown, L. (2009a). A failure of communication on the cross-cultural campus. Journal of Studies in International Education, 13(4), 439-454.

Casella, D.A., \& Brougham, C.E. (1995). What works: Student jobs open front doors to careers. Journal of Career Planning \& Employment, 55(4), 24-27.

Cheng, D.X., \& Alcántara, L. (2007). Assessing working students' college experiences: A grounded theory approach. Assessment \& Evaluation in Higher Education, 32(3), 301-311.

Choy, S.P. (2002). Access \& persistence: Findings from 10 years of longitudinal research on students. Washington, DC: ERIC.

Creswell, J.W. (2007). Qualitative inquiry \& research design: Choosing among five approaches. Thousand Oaks, CA: Sage.

Cross, W.E., Parham, T., \& Helms, J. (1991). The stages of Black identity development: Nigrescence models. In R.L. Jones (Ed.), Black psychology (pp. 319-338). Berkeley, CA: Cobb \& Henry.

Cuccaro-Alamin, S. (1997). Postsecondary persistence and attainment: Findings from "The Condition of Education, 1997," no. 13. Washington, DC: National Center for Education Statistics. Retrieved from https://eric.ed.gov/?id=ED412859

Ellis, R. (2008). The study of second language acquisition. Oxford: Oxford University Press.

Giorgi, A. (2008). Difficulties encountered in the application of the phenomenological method in the social sciences. Indo-Pacific Journal of Phenomenology, 8(1), 19.

Gresham, R., \& Clayton, V. (2011). Community connections: A programme to enhance domestic and international students' educational experience. Journal of Higher Education Policy \& Management, 33(4), 363-374.

Hail, H.C. (2015). Patriotism abroad: Overseas Chinese students' encounters with criticisms of China. Journal of Studies in International Education, 19(4), 311326.

Horn, L.J. (1998). Undergraduates who work: National postsecondary student aid study, 1996. Washington, DC: National Center for Education Statistics.

Horn, L.J., \& Maw, C. (1994). Undergraduates who work while enrolled in postsecondary education: 1989-90 (No. 0-16-045175-2). Berkeley, CA: National Center for Education Statistics.

Institute of International Education. (2017). Open doors fact sheet: China (Report on International Educational Exchange). Retrieved from https://p.widencdn.net/ymtzur/Open-Doors-2017-Country-Sheets-China

Kim, E. (2012). An alternative theoretical model: Examining psychosocial identity development of international students in the United States. College Student Journal, 46(1), 99-113.

Kim, Y.Y. (2000). Becoming intercultural: An integrative theory of communication and cross-cultural adaptation. Thousand Oaks, CA: Sage Publications. 
Lammers, W.J., Onwuegbuzie, A.J., \& Slate, J.R. (2001). Academic success as a function of the gender, class, age, study habits, and employment of college students. Research in the Schools, 8(2), 71-81.

Lichtman, M. (2013). Qualitative research in education: A user's guide. Thousand Oaks, CA: SAGE Publications.

Melnick, G.A., Kaur, G., \& Yu, J. (2011). Social integration and academic outcomes: The case of an international public policy and management program. Journal of Public Affairs Education, 17(4), 569-584.

Merriam, S.B. (2009). Qualitative research: A guide to design and implementation. San Francisco, CA: Jossey-Bass.

Morse, J. (1994). Designing funded qualitative research. In N.K. Denzin \& Y.S. Lincoln (Eds.), Handbook of qualitative research (pp. 220-235). Thousand Oaks, CA: Sage Publications.

Oberg, K. (1960). Cultural shock: Adjustment to new cultural environments. Practical Anthropology, 7, 177-182.

Pascarella, E.T., Edison, M.I., Nora, A., Hagedorn, L.S., \& Terenzini, P.T. (1998). Does work inhibit cognitive development during college? Educational Evaluation and Policy Analysis, 20(2), 75-93.

Patton, M.Q. (2014). Qualitative research \& evaluation methods: Integrating theory and practice (4th ed.). Thousand Oaks, CA: SAGE Publications.

Phinney, J.S. (1993). A three-stage model of ethnic identity development in adolescence. In M.E. Bernal \& G.P. Knight (Eds.), Ethnic identity: Formation and transmission among Hispanics and other minorities. Albany, New York: State University of New York Press.

Poyrazli, S., Kavanaugh, P.R., Baker, A., \& Al-Timimi, N. (2004). Social support and demographic correlates of acculturative stress in international students. Journal of College Counseling, 7(1), 73-82.

Redden, E. (2014, August 20). Are international students satisfied? Retrieved October 30, 2015, from https://www.insidehighered.com/news/2014/ 08/20/new-survey-offers-insights-international-student-satisfaction-threecountries

Robinson, H.A., Wolffe, R., Hunt, P.S., \& Hoerr, N.A. (2002). Creating cross-cultural connections. Urban Education, 37(4), 533-547.

Rose-Redwood, C.R., \& Rose-Redwood, R.S. (2013). Self-segregation or global mixing? Social interactions and the international student experience. Journal of College Student Development, 54(4), 413-429.

Salisbury, M.H., Pascarella, E.T., Padgett, R.D., \& Blaich, C.F. (2012). The effects of work on leadership development among first-year college students. Journal of College Student Development, 53(2), 300-324.

Schlossberg, N.K. (1984). Counseling adults in transition: Linking practice with theory. New York: Springer Publication Co.

Schlossberg, N.K. (2011). The challenge of change: The transition model and its applications. Journal of Employment Counseling, 48(4), 159-162.

Scribner, S., \& Cole, M. (1973). Cognitive consequences of formal and informal education (Vol. 73). Science, 182(4112), 553-559.

Sherry, M., Thomas, P., \& Chui, W.H. (2010). International students: A vulnerable student population. Higher Education, 60(1), 33-46. 
Strange, C.C., \& Banning, J.H. (2001). Educating by design: Creating campus learning environments that work (1st ed.). San Francisco, CA: Jossey-Bass.

$\mathrm{Su}$, M., \& Harrison, L.M. (2016). Being wholesaled: An investigation of Chinese international students' higher education experiences. Journal of International Students, 6(4), 905-919.

Trice, A.G. (2004). Mixing it up: International graduate students' social interactions with American students. Journal of College Student Development, 45(6), 671687.

Tung, W. (2011). Acculturative stress and help-seeking behaviors among international students. Home Health Care Management \& Practice, 23(5), 383-385.

United States Government Accountability Office. (2014). State funding trends and policies on affordability (No. GAO-15-151). Retrieved from http://www.gao.gov/assets/670/667557.pdf

Volet, S.E., \& Ang, G. (1998). Culturally mixed groups on international campuses: An opportunity for inter-cultural learning. Higher Education Research \& Development, 17(1), 5-23.

Ward, C.A., Bochner, S., \& Furnham, A. (2001). The psychology of culture shock. Philadelphia: Routledge.

Ward, C.A. (2001). The impact of international students on domestic students and host institutions. New Zealand Ministry of Education. Retrieved from https://www.educationcounts.govt.nz/publications/international/the_impact_of international_students_on_domestic_students_and_host_institutions

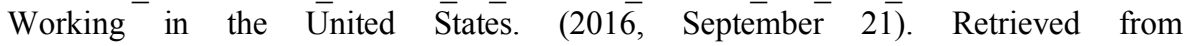
https://studyinthestates.dhs.gov/working-in-the-united-states

Xie, D., Leong, F., \& Feng, S. (2008). Culture-specific personality correlates of anxiety among Chinese and Caucasian college students. Asian Journal of Social Psychology, 11(2), 163-174.

Yang, B., Teraoka, M., Eichenfield, G.A., \& Audas, M.C. (1994). Meaningful relationships between Asian international and U.S. college students: A descriptive study. College Student Journal, 28(1), 108-115.

Ye, J. (2006). Traditional and online support networks in the cross-cultural adaptation of Chinese international students in the United States. Journal of ComputerMediated Communication, 11(3), 863-876.

MENGWEI SU, $\mathrm{PhD}$, is a recent graduate of the Patton College of Education at Ohio University. His major research interests lie in the area of campus internationalization through teaching, research, and outreach services. Email: ms306201@ohio.edu 